Jurnal Kejuruteraan SI 1(3) 2018: 57-62

http://dx.doi.org/10.17576/jkukm-2018-si1(3)-08

\title{
Pulsed Laser Annealing of Ag-Paste on $n$-Doped Emitter
}

\author{
(Sepuhlindapan Laser Denyut Pes Perak di Atas Pemancar Jenis- $n$ ) \\ Siti Nor Fazlina Abdul Hamida*, Suhaila Sepeai ${ }^{\mathrm{a}}$, Saleem H. Zaidi ${ }^{\mathrm{a}}$ \\ ${ }^{a}$ Solar Energy Research Institute, Universiti Kebangsaan Malaysia, Malaysia \\ Samir Mahmmod Ahmad ${ }^{\mathrm{b}}$ \\ ${ }^{b}$ Faculty of Science, University of Mosul, Iraq
}

\begin{abstract}
Pulsed laser sources are attractive on account of their spatial and temporal controllability at room temperature. Pulsed lasers, in visible (VIS) $(300-515 \mathrm{~nm})$ and infrared (IR) $(900-1064 \mathrm{~nm})$ spectral ranges, with pulse widths in micro to femtoseconds range, are used in a wide range of applications including doping, etching, texturing and deposition. In this study, an Nd-YAG dicing laser operating at $1064 \mathrm{~nm}$ wavelength with 200 nanosecond pulse duration has been employed to form silver ohmic contacts to an n-type emitter on a p-type silicon substrate. The laser beam was used to anneal screenprinted Ag polymer paste over a broad ( 7 to $500 \mathrm{~mJ} / \mathrm{cm}^{2}$ ) range of laser fluences. Computer numerical control software allowed fabrication of geometrical patterns with controllable diameters in 50-150- $\mu$ m range. Contact resistance measurements were performed using the transmission line method (TLM). Contact resistivity exhibited fast decay from very large values to relatively constant as a function of laser fluence. This variation was attributed to laser energy below the threshold energy which no alloyed Ag/Si contact could be formed. The lowest contact resistivity at $200 \mathrm{~m} \Omega . \mathrm{cm}^{2}$ was measured at 35 $\mathrm{mJ} / \mathrm{cm}^{2}$. This value was two orders of magnitude higher than the lowest value for thermally annealed contacts. For the laser parameters investigated here, optimum laser fluences were in $0.2-0.6 \mathrm{~J} / \mathrm{cm}^{2}$ range. It may be possible to attain lower resistivity values trough post-laser annealing.
\end{abstract}

Keywords: Laser-fired contacts; metallization; pulsed laser; silicon solar cells; front contact

ABSTRAK

Sumber laser denyut mempunyai kelebihan kerana keboleh-kawalan ruang dan masa pada suhu bilik. Laser denyut, dalam julat spektrum nampak (VIS) (300-515 nm) dan inframerah (IR) ( 900-1064 nm), dengan lebar denyutan dalam julat mikro hingga femtosaat, telah digunakan dalam pelbagai aplikasi termasuk pendopan, pemunaran, penteksturan dan pemendapan. Dalam kajian ini, pengguris laser Nd-YAG beroperasi pada panjang gelombang $1064 \mathrm{~nm}$ dengan tempoh denyutan 200 nanosaat telah digunakan untuk membentuk sentuhan ohmik perak pada pemancar jenis-n di atas substrat silikon jenis- $p$. Alur laser telah digunakan untuk menyepuh-lindapkan pes polimer perak yang dicetak skrin dengan meliputi julat kelancaran laser yang luas ( 7 hingga $\left.500 \mathrm{~mJ} / \mathrm{cm}^{2}\right)$. Perisian kawalan numerik komputer pula membolehkan fabrikasi pola geometri dengan julat diameter boleh kawal dalam julat 50-150 $\mu$ m. Pengukuran rintangan sentuhan telah dijalankan menggunakan kaedah garis penghantaran (TLM). Kerintangan sentuhan memperlihatkan susutan pantas dari nilai yang sangat besar kepada nilai malar secara relatif dengan fungsi kelancaran laser. Variasi ini disumbangkan oleh tenaga di bawah tenaga ambang laser yang tidak boleh membentuk hubungan Ag/Si aloi. Kerintangan sentuhan yang paling rendah pada nilai 200 $m \Omega . \mathrm{cm}^{2}$ telah diukur pada $35 \mathrm{~mJ} / \mathrm{cm}^{2}$. Nilai ini adalah dua peringkat magnitud lebih tinggi daripada nilai terendah bagi sentuhan sepuh lindap terma. Bagi parameter laser yang digunakan dalam penyiasatan ini, kelancaran laser yang optimum berada dalam julat 0.2-0.6 J/cm². Nilai kerintangan yang lebih rendah mungkin dapat dicapai melalui pasca penyepuh lindapan laser.

Kata kunci: Sentuhan berbakar-laser; perlogaman; denyut laser; sel suria silikon; sentuhan hadapan

\section{INTRODUCTION}

Ohmic electrical contact formation in industrially produced $n$-doped, $p$-type crystalline silicon $(\mathrm{Si})$ solar cells is based on simultaneous high temperature rapid thermal annealing of front surface silver $(\mathrm{Ag})$ and rear surface aluminum (Al) metallic pastes (Soin \& Majlis 2006). Screen printing of $\mathrm{Ag}$ and $\mathrm{Al}$ pastes is attractive due to its lower cost and high throughput in comparison with alternate expensive and slow techniques such as photolithography (Sepeai et al. 2011). The annealing process is carried out in conveyer belt type furnaces at temperatures up to $870^{\circ} \mathrm{C}$. For thinner wafers, particularly at high temperatures, (below $180 \mu \mathrm{m}$ ), thermal expansion mismatch between metal and Si results in excessive wafer bowing and stress that lower process yield (Popovich et al. 2013). It is therefore, desirable to develop alternate, ohmic metal/Si contact formation processes at either room temperature or lower $\left(<200^{\circ} \mathrm{C}\right.$ ) temperatures (Sakib \& Ahad 2018). 
Pulsed lasers have been used in materials processing for over 50 years (Sugioka et al. 2010) due to their unique controllability in spatial and temporal domains. Pulsed lasers have also been applied in solar cell processing including doping, deposition, etching, and annealing. Most laser work is focused on formation of $\mathrm{Al}$ film or paste to $p$-type $\mathrm{Si}$ wafers (Wang et al. 2013). Relatively little attention has been focused on formation of Ag contact to $n$-doped Si substrates. In this work, pulsed laser annealing of polymer Ag paste to $n$-doped Si wafers has been investigated as an alternative to expensive and high temperature conventional furnace-based rapid thermal annealing processes.

\section{OHMIC CONTACT}

An ideal ohmic contact is defined as a metal - semiconductor contact with negligible resistance relative to the bulk or spreading resistance of the semiconductor (Vinod 2011). It can be formed with metals exhibiting smaller work function than the semiconductor. In general, $\mathrm{Ag}$ does not form an ohmic contact as the $\mathrm{Ag}$ work function, $e \phi_{A g}(\sim 4.4 \mathrm{eV})$ is higher than Si electron affinity, $\chi_{s i}(\sim 4.4 \mathrm{eV})$. However, with a highly-doped emitter $\left(N_{D} \geq 10^{18}\right.$ atoms $\left./ \mathrm{cm}^{3}\right)$ region in physical contact with metal, an ohmic contact can be formed. This is due two facts: (a) lowering of the barrier height that allows thermionic emission current and (b) presence of thin $(\leq 100$ A) barrier layer for current flow direct tunneling current. In real devices, the formation of ohmic contacts requires; (a) highly doped surface layer to enhance tunneling, (b) appropriate combination of $\phi_{m}$ and $\chi_{i}$ to reduce $\phi_{b}$, and (c) defect states within the tunneling barrier region (Fahrenbruch \& Bube 1983).

\section{PULSED LASER SYSTEM}

For all the work reported, pulsed laser optical system based on a Q-switched Nd:YAG laser was employed. This pulsed laser was part of YMS-50D dicing system for Si wafers and solar cells. This laser operated at $1064 \mathrm{~nm}$ wavelength with pulse duration of 200 nanoseconds, modulating frequency of $50 \mathrm{kHz}$, and minimum spot size $\leq 0.05 \mathrm{~mm}$. The laser optical system is integrated with CNC system consisting of computercontrolled $x y$-wafer stages operating at maximum speed of $\sim 120 \mathrm{~mm} / \mathrm{s}$ to allow formation of any desired pattern; laser system specifications have been summarized in Table 1.

TABLE 1. YMS-50D laser system specifications

\begin{tabular}{lc}
\hline \multicolumn{2}{c}{ Specifications } \\
\hline Laser working material & Semiconductor pump laser \\
Laser wavelength & $1064 \mathrm{~nm}$ \\
Max output power & $50 \mathrm{~W}$ \\
Beam quality & $\mathrm{M}^{2}<6$ \\
Laser output instability & $\leq \pm 3 \%$ \\
Modulating frequency & $50 \mathrm{kHz}$ \\
Power supply & $220 \mathrm{~V} \pm 10 \% 50 \mathrm{~Hz}$ \\
Whole machine power & $2 \mathrm{~kW}$ \\
Continuous operating hours & $>24 \mathrm{~h}$ \\
\hline
\end{tabular}

\section{LASER-MATERIAL INTERACTIONS}

Pulsed lasers find wide range of material processing applications on account of their ability to spatially and temporally resolve and control material etching or deposition rate (Sugioka et al. 2010). These inherent advantages allowed pulsed lasers to become a manufacturing tool in photovoltaic (PV). Based on its wavelength, laser radiation is either fully or partially absorbed in the material. Laser-material interactions will lead either to local heating through electronic excitation or by electron-phonon coupling.

The physical response of a material under laser incidence is a function its optical absorption as described in Figure 1. From the plotted data of spectral absorption as a function of wavelength for metals and semiconductors, it is noted that for all metals the absorption depths are short and independent of wavelength. For semiconductors, absorption depths are similar to metals at short wavelengths $(<500 \mathrm{~nm})$. At longer wavelengths, especially near the bandgap, absorption lengths increase by several orders of magnitude. Therefore, based on the choice of laser used especially for $\mathrm{Si}$, absorption depths can vary from few nanometers to hundreds of micrometers. When a pulsed laser, with energy higher than material ablation threshold is incident on a material surface, it initiates melting, vaporization, and recrystallization in the interaction region (Figure 2). This material removal also caused the dense vapor plume ejected that may contain solid and liquid clusters of material from the irradiated zone. Ablation threshold is the specific characteristic of the materials that usually depends on their melting and boiling points as well as the absorption coefficient at a particular wavelength. For crystalline Si, the absorption depth at $1064 \mathrm{~nm}$ laser radiation is over $100 \mu \mathrm{m}$ it is also the laser employed in work reported here.

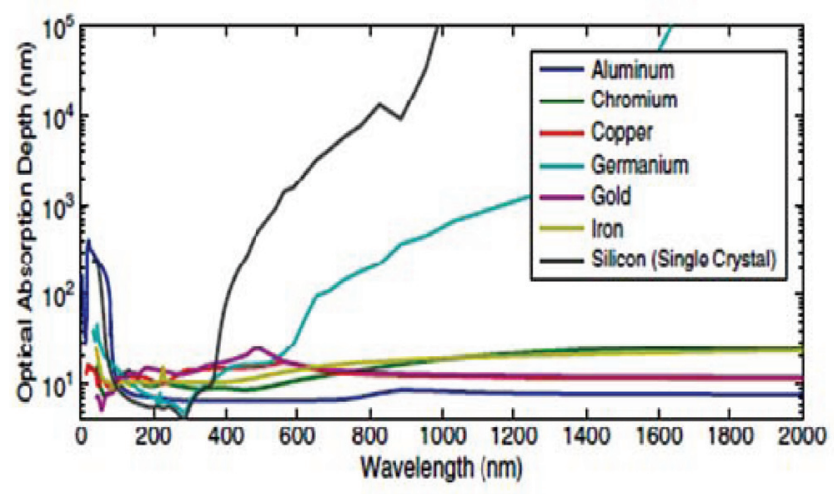

FIGURE 1. Optical absorption depth for several materials over a range of wavelengths (Arnold \& Brown 2010)

\section{TRANSMISSION LINE METHOD}

The measurement of contact resistivity is generally obtained by transmission line method (TLM). In TLM, the total resistance, $R_{\mathrm{T}}$ between two neighboring contact pads is measured as a function of increasing separation between them and plotted as a function of $d$. For the work reported here, a large TLM mask of pad dimensions $4 \times 10 \mathrm{~mm}^{2}$ with separation, $d$, varying started from $0.1 \mathrm{~mm}$ to $0.7 \mathrm{~mm}$ at an increment of $0.1 \mathrm{~mm}$ as seen in Figure 3 were used. 


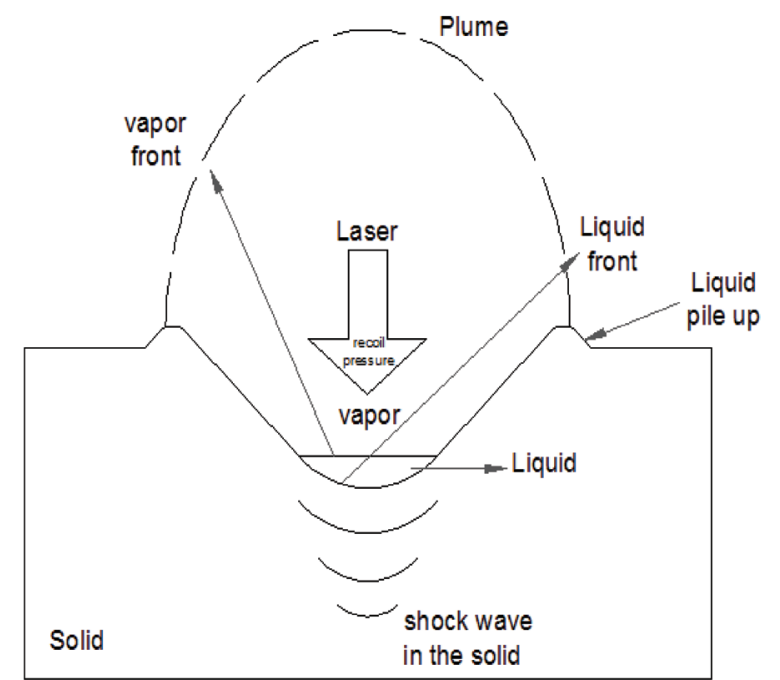

FIGURE 2. Schematic illustration of laser-material interaction

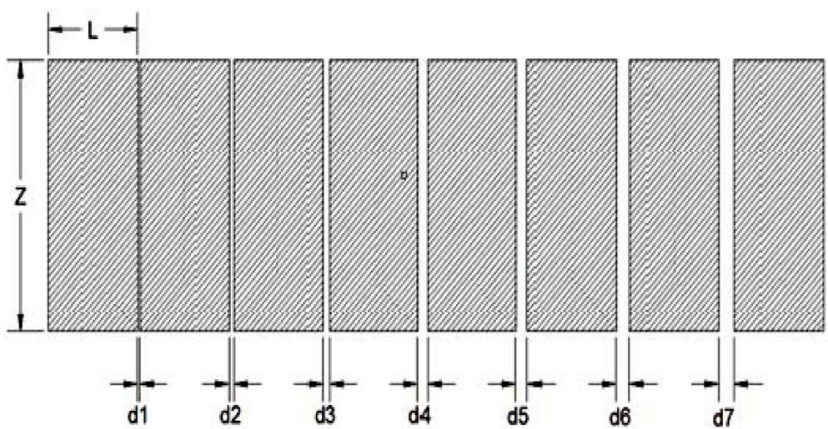

FIGURE 3. Top view of the TLM metallization pattern

METHODOLOGY

In earlier work (Ahmad et al. 2017) detailed analysis of temperature variation on metallization quality has been reported. The rapid thermal annealing experiments were performed in conveyor belt furnace in which wafer moves through six temperatures at constant speed. Results from these experiments are for comparing with laser annealed contacts using the same TLM mask.

For all the work reported here, polymer silver paste (Ferro LF33-750) was screen-printed on multicrystalline boron doped Si wafer with bulk resistivity of $0.5-3.0 \Omega . \mathrm{cm}$ and thickness of $200 \mu \mathrm{m}$, please see Figure 4 for details. Front surface of $\mathrm{Si}$ wafers were doped by standard $\mathrm{POCl}_{3}$ diffusion in a tube furnace to form an $n$-type emitter surface with a sheet resistance $50 \Omega / \mathrm{sq}$. Screen-printed contacts were dried in an oven for 10 minutes of at $150^{\circ} \mathrm{C}$ followed by laser-annealing for three different geometric patterns. Three different diameter configurations consisted of focused spots sizes with diameters of $0.05 \mathrm{~mm}, 0.10 \mathrm{~mm}$, and $0.15 \mathrm{~mm}$ at periodicity of $1 \mathrm{~mm}$. The resistivity Ag/Si contact was measured for all three configurations. Varied for all three cases Figure 5 illustrates TLM metallization pattern used for laser annealing of screen-printed polymer Ag paste. Several wafers were prepared with varying contact sizes while maintaining same range of pulsed energy. Contact size variation was achieved with the assistance of CNC software.

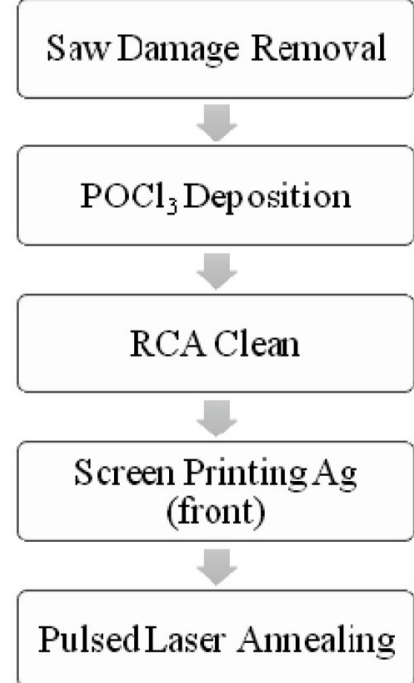

FIGURE 4. Process flow of pulsed laser annealing of front surface Ag paste contact

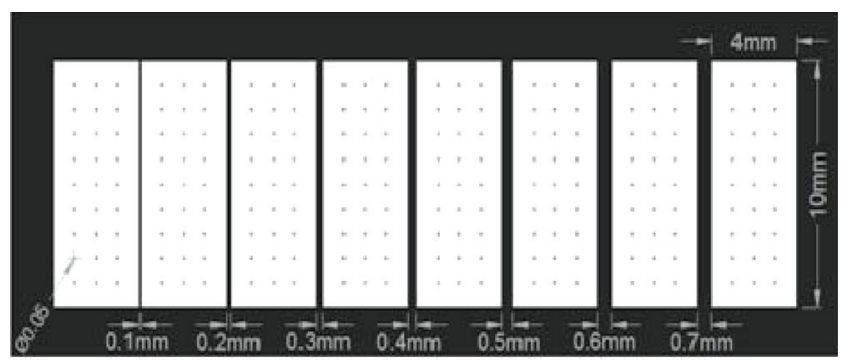

FIGURE 5. Screen-printed Ag paste by using TLM metallization pattern after laser annealing

RESULTS AND DISCUSSION

An extensive investigation of rapid thermal a of $\mathrm{Ag} / \mathrm{Si}$ contacts has been reported elsewhere (Ahmad et al. 2017). Since same TLM mask dimensions were used, it is worthwhile to briefly review thermally annealed contact results. Figure 6 plots resistivity as a function of temperature in 600$920^{\circ} \mathrm{C}$ temperature range. Resistivity exhibits four orders of magnitude reduction as temperature is increased from $\sim 600^{\circ} \mathrm{C}$ to $900^{\circ} \mathrm{C}$. A well-defined minimum is observed at $870^{\circ} \mathrm{C}$ after which resistivity starts to increase. The lowest contact resistance is less than $1 \mathrm{~m} \Omega \cdot \mathrm{cm}^{2}$ for the six-zone conveyer belt IR furnace. Clearly, laser-annealed contact exhibits contact resistivity higher by more than two orders of magnitude.

For this laser, the pulse width is 200 nano second and maximum pulse energy is 10 microjoule $(\mu \mathrm{J})$ giving maximum power is $50 \mathrm{~W}$ (pulse energy/pulse width). The minimum threshold energy at which contact resistivity could be measured was approximately $1.25 \mu \mathrm{J}$. Due to large laser spot dimension variations, it is important to plot resistivity as a function of laser fluence $\left(\mathrm{J} / \mathrm{cm}^{2}\right)$ by simply dividing pulse energy by the surface area. Figure 7 plots resistivity as a function of surface area for all three contact configurations. 


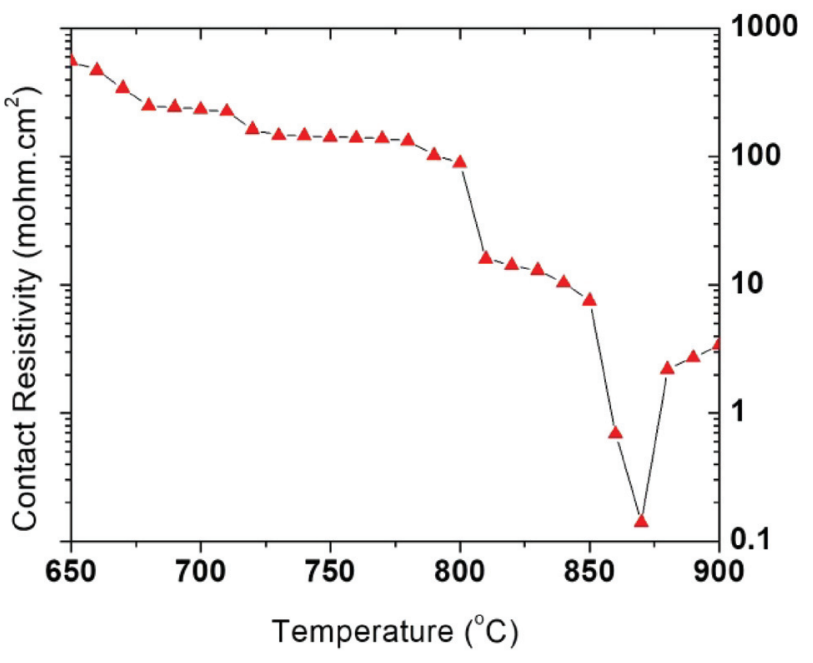

FIGURE 6. Resistivity of $\mathrm{Ag} / \mathrm{Si}$ contact as a function of temperature in thermal annealing configuration

The solid lines in Figure 7 represent curve-fitting to the experimental data. For the smallest focused spot size of $0.05 \mathrm{~mm}$, best fit was achieved with Lorentzian, 4 Parameter equation $\left(f=y_{0}+a /\left(1+\left(\left(x-x_{0}\right) / b\right)^{2}\right)\right.$. While for both larger diameters (0.1-0.15 mm), best fit was achieved with exponential decay, modified single, 3-parameter equation $\left(f=a \cdot e^{(b /(x+c))}\right)$.

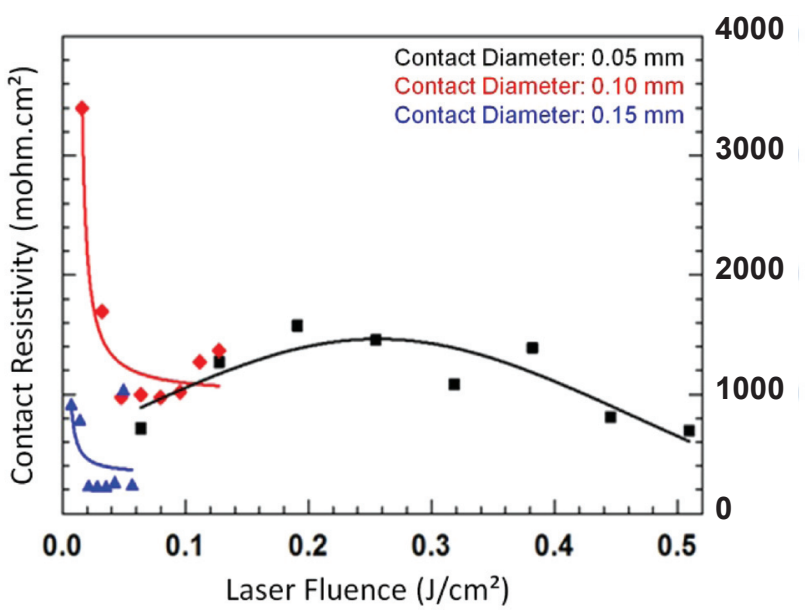

FIGURE 7. Resistivity of $\mathrm{Ag} / \mathrm{Si}$ contact as a function of laser fluence

Critical features of the resistivity measurements are summarized below.

1. Resistivity decreases as laser fluence increases,

2. Lowest resistivity is observed for the largest pattern and vice versa,

3. Resistivity is highest for lowest laser fluence and decreases rapidly as laser fluence is increased, and

4. Optimal laser fluence for lowest contact resistivity is in $0.2-0.6 \mathrm{~J} / \mathrm{cm}^{2}$ range.
Comparison of resistivity variation between thermal (Figure 6) and laser (Figure 7) annealed contacts reveal the following facts:

1. High resistivity at low temperatures during thermal annealing is similar to that of laser fluence below threshold value,

2. Thermal annealing contact response is linear whereas laser-based contact shows relatively invariant response once energy increases over the threshold value, and

3. Lowest laser-annealed resistivity at $\sim 200 \mathrm{~m} \Omega \mathrm{cm}^{2}$ is two orders of magnitude higher than thermally-annealed contact.

\section{EFFECT OF LASER PARAMETERS}

The range of laser fluences investigated here result in many effects including ablation and redeposit ion of the liquid metal/Si alloys onto the surface; referred to as liquid pile-up. At the end of the pulsed laser cycle, the re-deposited molten regions recrystallize instantaneously high cooling rates. Figure 8 shows scanning electron microscope (SEM) views of the pulsed-lased etched hole in Si substrate. The top SEM view (Figure 8-a) illustrates the evenly distributed and recrystallized Si on the top, sidewall, and bottom surfaces. The cross-sectional, high resolution SEM images of top (Figure 8-b) and bottom (Figure 8-c) surfaces illustrate the extent and thickness of the re-deposited materials. In this case, top surface re-deposition area generally extends up to $\sim 100-\mu \mathrm{m}$ from the hole edge while the thickness of deposited films ranges in 20-30 $\mu \mathrm{m}$. During pulsed laser surface melting, some of top Si surface is likely lost due to evaporation. Therefore, it is inherently difficult to compare thermal and laser annealing processes.

Laser-material interactions are fundamentally different than the thermal annealing processes for contact formation. The absorbed laser energy on the $\mathrm{Ag} / \mathrm{Si}$ interface raises temperature of both the paste and $\mathrm{Si}$ substrate. Below threshold energy, no alloyed contact is possible between $\mathrm{Ag}$ and $\mathrm{Si}$, hence the very high resistivity values. This behavior is identical for laser and thermal annealing experiments. As laser fluence is increased, laser energy melts $\mathrm{Ag} / \mathrm{Si}$ interface and penetrates into the $\mathrm{Si}$ substrate. The absorbed laser energy is not significantly absorbed at Si surface due to its weak Si absorption at $1064 \mathrm{~nm}$ wavelength. At the interface, complex mixture of solid, liquid, and vapor phases is formed that extends well below the interface into the bulk region of the sample (Figure 9).

\section{CONCLUSION}

Pulsed laser annealing of polymer Ag contact on n-type emitter has been investigated using TLM approach. Three laser pattern configurations were investigated with laser fluence varying from $\sim 7$ to $500 \mathrm{~mJ} / \mathrm{cm}^{2}$. Lowest contact resistance at $200 \mathrm{~m} \Omega . \mathrm{cm}^{2}$ was observed at laser fluence of $\sim 35 \mathrm{~mJ} / \mathrm{cm}^{2}$, which were approximately two orders of magnitude higher 


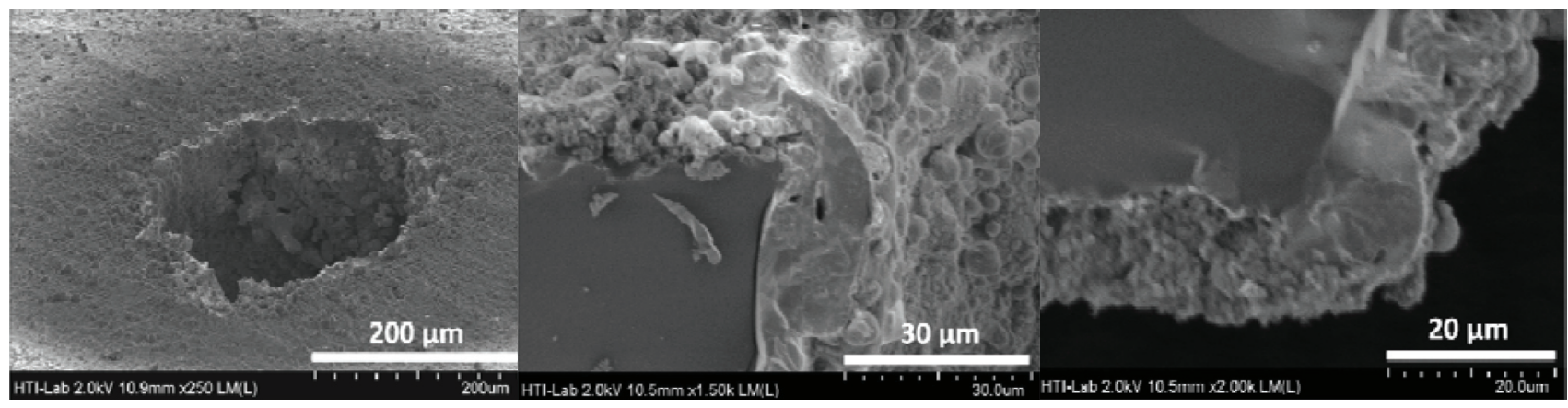

(a)

(b)

(c)

FIGURE 8. Scanning electron microscope pictures of pulsed laser etched hole in Si showing top (a), cross-sectional top views of top (b), and the bottom (c) interfaces
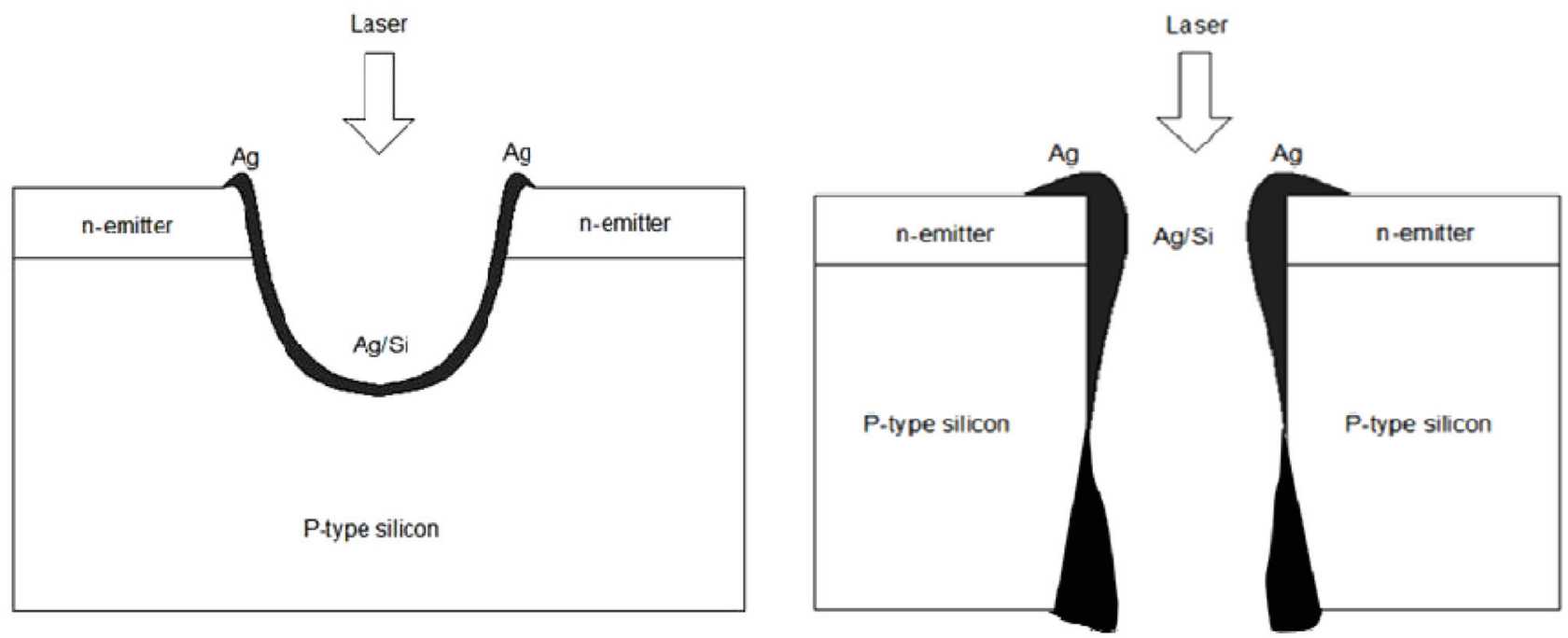

FIGURE 9. Schematic illustration of laser-material interactions at (left) lower energy and (right) higher energy

than thermally-annealed contacts. High contact resistivities of laser-annealed contacts are attributed to the complex nature of liquid-vapor interface as well as the long absorption length of Nd-YAG laser in Si. Optimum configuration is observed between laser fluences in $\sim 0.1-0.3 \mathrm{~J} / \mathrm{cm}^{2}$ range for the largest spot sizes. At larger fluences, loss of doped $\mathrm{Si}$ in emitter region is higher due to ablation and vaporization. Contact resistance may be reduced through post laser annealing in hydrogen ambient.

\section{ACKNOWLEDGEMENT}

The authors would like to acknowledge the financial support from the MOSTI and Solar Energy Research Institute, Universiti Kebangsaan Malaysia. The authors would like to thank Ministry of Science, Technology and Innovation (MOSTI) for supporting this work through Science fund grant (03-01-02-SF1322) and Ministry of Higher Education for PRGS grant (PRGS/1/2017/TK07/UKM/01/1).
REFERENCES

Ahmad, S.M., Leong, C.S., Sopian, K. \& Zaidi, S.H. 2017. Role of firing temperature, sheet resistance, and contact area in contact formation on screen-printed metal contact of silicon solar cell. Journal of Electronic Materials 47(3): 2120-2134.

Arnold, C.B. \& Brown, M.S. 2010. Fundamentals of lasermaterial interaction and application to multiscale surface modification. Laser Precision Microfabrication 91-120.

Fahrenbruch, A.L. \& Bube, R.H. eds. 1983. Fundamentals of Solar Cells: Photovoltaic Solar Energy Conversion. Academic Press, Inc.

Popovich, V.A, van Maris, M.P.F.H.L., Janssen, M., Bennet, I.J. \& Richardson, I.M. 2013. Understanding the properties of silicon solar cells aluminum contact layers and its effect on mechanical stability. Material Sciences and Applications 4(2): 118-127.

Sakib, N. \& Ahad, M.A.R. 2018. An optimized structure for enhancing optical absorption of solar energy in elliptical GaAs nanowire array solar cell. Jurnal Kejuruteraan 30(1): 1-6. 
Sepeai, S., Sulaiman, M. Y., Zaidi, S.H. \& Sopian, K. 2011. Microstructural studies on fire-through front contact metallization of si solar cells. IEEE Regional Symposium on Micro and Nano Electronics 2011, Proceedings 461-464.

Soin, N. \& Majlis, B.Y. 2006. Development of design method and Silicon corrugated diaphragm using $\mathrm{KOH}$ an-isotropic etching. Jurnal Kejuruteraan 18: $147-160$.

Sugioka, K., Meunier, M. \& Pique, A. 2010. Laser Precision Microfabrication. Springer.

Vinod, P.N. 2011. Specific contact resistance measurements of the screen-printed Ag thick film contacts in the silicon solar cells by three-point probe methodology and TLM method. Journal Material Science: Material Electron 22(9): 1248-1257.

Wang, L., Carlson, D.E. \& Gupta, M.C. 2013. Investigation of metal contacts for silicon solar cells using laser processed $8 \mu \mathrm{m}$ thick Al foil. Proceeding of SPIE; 8826: 882604-1 $-882604-5$.
*Siti Nor Fazlina Abdul Hamid, Saleem H. Zaidi, Suhaila Sepeai

Solar Energy Research Institute (SERI),

Universiti Kebangsaan Malaysia, Bangi, Malaysia.

Samir Mahmmod Ahmad

Department of Physics,

Faculty of Science,

University of Mosul, Iraq.

*Corresponding author; email: fazlina.hamid@yahoo.com

Received date: $14^{\text {th }}$ May 2018

Accepted date: $17^{\text {th }}$ July 2018

Online first date: $1^{\text {st }}$ October 2018

Published date: $30^{\text {th }}$ November 2018 